\title{
Records of Anopheles (Nyssorhynchus) (Diptera, Culicidae) in artificial containers in Ribeirão Preto City, State of São Paulo, Brazil
}

\author{
Eliana Collucci ${ }^{1} \&$ Maria Anice Mureb Sallum $^{1}$
}

\begin{abstract}
${ }^{1}$ Núcleo de Pesquisa Taxonômica e Sistemática em Entomologia Médica, Departamento de Epidemiologia, Faculdade de Saúde Pública, Universidade de São Paulo, Av. Dr. Arnaldo 715, 01246-904 São Paulo-SP, Brasil. 'Corresponding author. elicollucci@usp.br
\end{abstract}

\begin{abstract}
Records of Anopheles (Nyssorhynchus) (Diptera, Culicidae) in artificial containers in Ribeirão Preto City, State of São Paulo, Brazil. Thirty immatures of Anopheles darlingi Root, Anopheles argyritarsis Robineau-Desvoidy and Anopheles rondoni (Neiva \& Pinto) (were found in an artificial lagoon situated near Pardo River, in Ribeirão Preto City, State of São Paulo, Brazil. The presence of immatures of Anopheles darlingi breeding in a lagoon is suggestive of the potential capacity of that species to adapt and occupy new habitats and to invade urban areas along the species distribution range and also disperse to new localities.
\end{abstract}

KEYWORDS. Anopheles darlingi; immature; urban area.

RESUMO. Registro de Anopheles (Nyssorhynchus) (Diptera, Culicidae) em recipientes artificiais em Ribeirão Preto, São Paulo, Brasil. Trinta espécimes imaturos de Anopheles darlingi Root, Anopheles argyritarsis Robineau-Desvoidy e Anopheles rondoni (Neiva \& Pinto) foram encontrados em lagoa artificial situada nas proximidades do Rio Pardo, em Ribeirão Preto, Estado de São Paulo, Brasil. A presença das formas imaturas de Anopheles darlingi criando-se em lagoa artificial sugere que a espécie tem potencial tanto para se adaptar e ocupar novos habitats como para invadir áreas urbanas ao longo da distribuição geográfica e também de se dispersar para novas localidades.

PALAVRAS-CHAVE. Anopheles darlingi; imaturos; área urbana.

Anophelines are mainly standing or slow moving, shade water breeding mosquitoes. Immatures can be found either in temporary or semi-permanent or permanent habitats, such as ground pools, ground pools along stream margins, flood pools, seepage pools, pools in stream banks, swamps and small shallow running streams. It has been considered that only a few species of Anophelinae breed in natural containers and to find immatures in artificial containers was considered to be unusual by Forattini et al. (1998).

Anopheles darlingi is the main vector of human Plasmodium in Brazil. This species is widespread in Latin America, from south Mexico to southern Brazil. The breeding habitats are represented by sites situated in low altitude areas, usually in floating debris along river margins, lake margins, small lagoons, ground pools with submerged roots and patches of floating leaves or vegetation (Manguin et al. 1996).

Ribeirão Preto was an important area of autochthonous malaria transmission until middle of the 20th century. Autochthonous malaria transmission was eliminated from that site in the 1950s thanks to the Eradication Malaria Control Program carried out in the State of São Paulo (Alves et al. 2004). Currently, all malaria cases reported in Ribeirão Preto are considered to be imported from regions were malaria is autochthonous.

The geographical distribution range of Anopheles species (especially of members of the subgenus Nyssorhynchus) extends to Ribeirão Preto municipality. In this city, it is not unusual to find larvae of Nyssorhynchus species in artificial containers, especially in peri-urban and countryside areas. Aedes aegytpi (Linnaeus), Ae. albopictus Say and Culex quinquefasciatus Say are usually found in association with Anopheles (Nyssorhynchus) species.

During an inspection carried out by the staff of the Centro de Controle de Vetores on 30rd August 2005 and 14th September 2005, in a sport country club situated in urban area in Ribeirão Preto municipality, it were found 30 anophelines larvae, which were identified as of the Nyssorhynchus subgenus. Second-, third- and fourth-instars larvae were encountered in a pond inside the club area. The pond is situated a few meters from

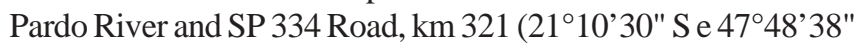
W), $518 \mathrm{~m}$ above sea level. The pond is 700 meters length, 200 meters wide, and its maximum deep is 2.5 meters. It is used only for recreation and sport fishing, is well preserved and its water is constantly renewed.

One adult female emerged seven days later after sampling of immatures on 30th August 2005. The associated larval and pupal skins are preserved on a microscope slide in Canadian balsam. The adult female was mounted in a white, paper triangle in an entomological pin. The specimen was identified as $A n$. darlingi in NUPTEM / FSP-USP. Four female adults collected 
in the same site on the 14th September 2005 were identified as An. argyritasis Robineau-Desvoidy and An. rondoni (Neiva $\&$ Pinto). The specimens were identified using both Forattini's (2002) and Consoli \& Lourenço-de-Oliveira's (1994) identification keys. Voucher specimens were deposited at Faculdade de Saúde Pública, Universidade de São Paulo.

Epidemiological importance of the presence of immatures of An. darlingi breeding in an artificial pond situated in the urban area of Ribeirão Preto, at this moment, should not cause major concern. However, the species can play important role in regional malaria transmission in the future. Considering that Anopheles darlingi has potential to adapt to urban environment, thus finding immatures in a pond corroborates this hypothesis. Póvoa et al. (2003) evaluated the distribution and dispersion of human malaria parasite vectors in Belém in the last 70 years. Although the species had been eliminated from Belém in 1968, it reinfested the area and is becoming more problematic and abundant since the middle 1990s. It is interesting to point that Nyssorhynchus species in Belém area raised from two species in the 1930s to ten species in 1990s. At the same time, it has been observed a great increase in malaria incidence and prevalence since the late 1970s. A tendency of having urban malaria has been reported in Macapá municipality, Amapá State (Conn et al. 2002) and in Manaus, Amazonas State. Human activities have increased the availability of breeding places for some vector species present in low density in the natural ecosystem (Ferreira-Gonçalves \& Alecrim 2003). Obviously, presence of An. darlingi in Ribeirão Preto, in a site near the Pardo River, can be considered occasional or normal, because this species occurs in ciliar forest along the river, however having immatures breeding in a pond is suggestive of the potential capacity of that species to adapt and occupy new habitats and thus to domiciliate and to invade urban areas along the species distribution range and also disperse to new localities. As regards to Ribeirão Preto the risk of having malaria transmission exists, although being low, and the presence of the main human plasmodium vector in an urban area should be dealt with caution.

Acknowledgments. We thanks FAPESP for financial support, Grant \# 05/53973-0 to MAMS. Flávio, Tânia, Antônia, and Luciano from the Divisão de Controle de Vetores, Centro de Controle de Zoonoses, Secretaria Municipal da Saúde de Ribeirão Preto for helping with mosquito collections.

\section{REFERENCES}

Alves, M. J. C. P.; R. C. Mayo \& M. R. Donalisio. 2004. História, epidemiologia e controle da malária na região de Campinas, Estado de São Paulo, Brasil, 1980 a 2000. Revista da Sociedade Brasileira de Medicina Tropical 37: 41-45.

Conn, J. E.; R. C. Wilkerson; M. N. Segura; R. T. de Souza; C. D. Schlichting; R. A.Wirtz \& M. M. Póvoa. 2002. Emergence of a new neotropical malaria vector facilitated by human migration and changes in land use. American Journal of Tropical Medicine and Hygiene: $18-22$.

Consoli, R. A. G. B. \& R. Lourenço-de-Oliveira. 1994. Principais mosquitos de importância sanitária no Brasil. Fundação Oswaldo Cruz, Rio de Janeiro, 228 p.

Ferreira-Goncalves, M. J. \& W. D. Alecrim. 2004. Non-planned urbanization as a contributing factor for malaria incidence in Manaus-Amazonas, Brazil. Revista de Salud Publica 6: 15666.

Forattini, O. P.; I. Kakitani; G. R. A. M. Marques \& M. Brito. 1998. Formas imaturas de anofelíneos em recipientes artificiais. Revista de Saúde Pública 32: 189-91.

Forattini, O. P. 2002. Culicidologia Médica, vol. 2, Edusp, São Paulo, 860 p.

Manguin, S.; D. R. Roberts; R. G. Andre; E. Rejmankova \& S. Hakre. 1996. Characterization of Anopheles darlingi (Diptera: Culicidae) larval habitats in Belize, Central America. Journal of Medical Entomology 33: 205-11.

Póvoa, M. M.; J. E. Conn; C. D. Schlichting; J. C. Amaral; M. N. Segura; A. N. da Silva; C. C. dos Santos; R. N. Lacerda; R. T. de Souza; D. Galiza; E. P. Santa Rosa \& R. A. Wirtz. 2003. Malaria vectors, epidemiology, and the re-emergence of Anopheles darlingi in Belém, Pará, Brazil. Journal of Medical Entomology 40: 379-86.

Received 06/12/2005; accepted 12/07/2006 